\title{
PENERAPAN MODEL PEMBELAJARAN KOOPERATIF TIPE STAD PADA PEMBELAJARAN MENGIDENTIFIKASI JENIS MAKANAN HEWAN DI SD
}

\section{Ocih Sukaesih}

SDN Jatiroke I Jatinangor

Jl. Letda Lukito No. 56 Jatinangor Sumedang

Email: ocih@yahoo.com

\begin{tabular}{|c|c|}
\hline ABSTRACT & ABSTRAK \\
\hline $\begin{array}{l}\text { Students grade IV of Jatiroke I Elementary School, } \\
\text { Jatinangor Sumedang, have many difficulties in } \\
\text { completing the learning to identify the type of } \\
\text { animal food in science learning. As an effort to } \\
\text { solve the problems is implementing cooperative } \\
\text { learning model, such as student teams } \\
\text { achievement divisions (STAD), through classroom } \\
\text { action research. Based on the research results, } \\
\text { cycle 1 give a significant increasing } \\
\text { achievement. The acquisition value of } 18 \\
\text { students who scored in the top } 70 \text { increased to } \\
10 \text { students or } 55 \% \text {. In cycle } 2 \text {, all students (100\%) } \\
\text { scored in the top } 70 .\end{array}$ & $\begin{array}{l}\text { Siswa Kelas IV SD Negeri Jatiroke I Jatinangor } \\
\text { Kabupaten Sumedang mengalami kesulitan } \\
\text { dalam menyelesaikan pembelajaran } \\
\text { mengidentifikasi jenis makanan hewan pada } \\
\text { pembelajaran IPA. Upaya yang dilakukan } \\
\text { adalah dengan penggunaan model } \\
\text { pembelajaran kooperatif tipe student teams } \\
\text { achievement divisions (STAD) melalui penelitian } \\
\text { tindakan kelas. Berdasarkan hasil penelitian, } \\
\text { pada siklus 1 telah terjadi peningkatan yang } \\
\text { signifikan dalam pembelajaran pembelajaran } \\
\text { mengidentifikasi jenis makanan hewan, yaitu } \\
\text { pemerolehan nilai dari } 18 \text { siswa yang } \\
\text { mendapatkan nilai di atas } 70 \text { bertambah } \\
\text { menjadi } 10 \text { siswa atau } 55 \% \text {. Pada siklus 2, semua } \\
\text { siswa (100\%) mendapatkan nilai di atas 70. } \\
\text { Kata kunci: pembelajaran kooperatif, STAD, IPA, } \\
\text { hewan. }\end{array}$ \\
\hline
\end{tabular}

How to Cite: SUkaesih, O. (2015). PENERAPAN MODEL PEMBELAJARAN KOOPERATIF TIPE STAD PADA PEMBELAJARAN MENGIDENTIFIKASI JENIS MAKANAN HEWAN DI SD. Mimbar Sekolah Dasar, 2(1), $46-59$. doi:http://dx.doi.org/10.17509/mimbar-sd.v2i1.1321.

PENDAHULUAN Melalui Kurikulum Tingkat Satuan Pendidikan (KTSP) 2006, pelajaran Ilmu Pengetahuan Alam sudah dimulai dari kelas I meskipun pembelajarannya tematik. Dalam KTSP (Depdiknas, 2006). mata pelajaran IImu Pengetahuan Alam (IPA) di sekolah dasar (SD) bertujuan:

1. Memperoleh keyakinan terhadap kebesaran Tuhan Yang Maha Esa berdasarkan keberadaan, keindahan dan keteraturan alam ciptaan-Nya.

2. Mengembangkan pengetahuan dan pemahaman konsep-konsep IPA yang bermanfaat dan dapat diterapkan dalam kehidupan sehari-hari.

3. Mengembangkan rasa ingin tahu, sikap positif dan kesadaran tentang adanya hubungan yang saling mempengaruhi antara IPA, lingkungan, teknologi dan masyarakat.

4. Mengembangkan ketrampilan proses untuk menyelidiki alam sekitar, memecahkan masalah dan membuat keputusan.

5. Meningkatkan kesadaran untuk berperan serta dalam memelihara, 
menjaga dan melestarikan lingkungan alam.

6. Meningkatkan kesadaran untuk menghargai alam dan segala keteraturannya sebagai salah satu ciptaan Tuhan.

7. Memperoleh bekal pengetahuan, konsep dan keterampilan IPA sebagai dasar untuk melanjutkan pendidikan ke SMP/MTs.

Secara umum tujuan pendidikan IImu Pengetahuan Alam dalam kurikulum adalah mendidik siswa agar memahami konsep IImu Pengetahuan Alam, memiliki keterampilan ilmiah, bersikap ilmiah dan religius. Cara mencapai ketujuh tujuan pendidikan IImu Pengetahuan Alam di atas, tentu tidak serta-merta dapat dicapai oleh materi pelajaran IImu Pengetahuan Alam, tetapi bagaimana cara melibatkan siswa ke dalam kegiatan di dalamnya.

Keseluruhan tujuan dan tuntutan berkenaan dengan pendidikan IImU Pengetahuan Alam di sekolah dasar, semestinya diupayakan oleh guru IImu Pengetahuan Alam secara simultan dan integral. Namun, pembelajaran IImU Pengetahuan Alam di sekolah dasar, pada umumnya belum seperti apa yang diharapkan. Pada pelaksanaannya tujuan pembelajaran IImu Pengetahuan Alam sebagaimana tertuang dalam kurikulum telah direduksi menjadi sekadar pemindahan konsep-konsep yang kemudian menjadi bahan hapalan bagi siswa dan bahkan dalam bentuk latihanlatihan penyelesaian soal-soal tes, sematamata dalam rangka mencapai target kurikulum.

Pembelajaran Ilmu Pengetahuan Alam, seharusnya didasarkan pada karakteristik psikologis anak; memberikan kesenangan bermain dan kepuasan intelektual bagi mereka dalam membongkar masalahmasalah, seluk-beluk dan teka-teki fenomena alam sekitar dirinya; mengembangkan potensi IImu Pengetahuan Alam yang terdapat dalam dirinya; memperbaiki konsepsi mereka yang masih keliru tentang fenomena alam; sambil membekali keterampilan dan membangun konsep-konsep baru yang harus dikuasainya.

Hasil observasi awal yang dilakukan oleh peneliti di Kelas IV SD Negeri Jatiroke I Kecamatan Jatinangor Kabupaten Sumedang, menunjukkan rendahnya tingkat penguasaan siswa terhadap materi mengidentifikasi jenis makanan hewan. Hal ini terbukti hanya 6 siswa atau $33 \%$ dari 18 siswa yang menguasai materi mengidentifikasi jenis makanan hewan. Dari data di atas, maka siswa Kelas IV SD Negeri Negeri Jatiroke I Kecamatan Jatinangor Kabupaten Sumedang perlu mendapatkan perhatian dalam pembelajaran mengidentifikasi jenis makanan hewan supaya siswa tidak lagi mengalami kesulitan dalam menyelesaikan pembelajaran mengidentifikasi jenis makanan hewan, 
Ocih Sukaesih, Penerapan Model Pembelajaran Kooperatif...

maka upaya yang dilakukan oleh peneliti adalah dengan penggunaan model pembelajaran kooperatif tipe students teams achievement divisions (STAD) yang diharapkan dapat meningkatkan hasil belajar siswa dalam pembelajaran mengidentifikasi jenis makanan hewan pada mata pelajaran IPA.

Berdasarkan latar belakang tersebut, peneliti tertarik untuk mengangkat permasalahan ke dalam penelitian tindakan kelas dengan rumusan masalah sebagai berikut.

1. Bagaimana hasil belajar siswa tentang mengidentifikasi jenis makanan hewan pada pembelajaran IPA di kelas IV SD Negeri Jatiroke I Kecamatan Jatinangor Kabupaten Sumedang dengan menggunakan model pembelajaran kooperatif tipe STAD?

2. Bagaimana langkah pembelajaran mengidentifikasi jenis makanan hewan pada pembelajaran IPA di kelas IV SD Negeri Negeri Jatiroke I Kecamatan Jatinangor Kabupaten Sumedang dengan menggunakan model pembelajaran kooperatif tipe STAD?

\section{Hakikat IPA}

Keberadaan alam ini penuh dengan keragaman, tetapi juga penuh dengan tatanan kehidupan yang menghiasi alam semesta. Pada prinsipnya IImu Pengetahuan Alam menawarkan caracara agar dapat memahami kejadiankejadian di alam dan agar kita dapat hidup di alam ini untuk menggunakan alam ini. Pada hakikatnya IImu Pengetahuan Alam sebagai produk tidak dapat dipisahkan dari hakikatnya sebagai proses. Produk IImu Pengetahuan Alam adalah fakta-fakta, konsep-konsep dan prinsip-prinsip, serta teori-teori. Prosedur yang dipergunakan oleh para ilmuwan untuk mempelajari alam ini adalah prosedur empirik dan analisis.

Para ilmuwan mengumpulkan informasi ke dalam prosedur empirik untuk mengorganisasikan informasi untuk selanjutnya dianalisis. Proses empirik dalam IImu Pengetahuan Alam mencakup observasi (pengamatan), klasifikasi dan pengukuran. Sedangkan dalam prosedur analitis ilmuwan menginterpretasikan penemuan mereka dengan mempergunakan proses-proses seperti hipotesis, eksperimentasi terkontrol, menarik simpulan dan memprediksi. Untuk menjalankan suatu penelitian tentang alam diperlukan pengetahuan alam terpadu tentang proses dan materi dalam topik yang akan diselidiki.

\section{Ilmu Pengetahuan Alam sebagai Produk}

Kata IImu Pengetahuan Alam merupakan terjemaahan dari kata-kata bahasa Inggris natural science, secara singkat sering disebut science. Natural artinya alamiah, berhubungan dengan alam, atau bersangkut paut dengan alam. Science artinya ilmu pengetahuan, jadi IImu Pengetahuan Alam secara harfiah dapat disebut sebagai llmu tentang alam ini, ilmu yang mempelajari peristiwa-peristiwa yang terjadi di alam. 
IImu Pengetahuan Alam sebagai disiplin disebut juga sebagai produk IImu Pengetahuan Alam. Ini merupakan kumpulan hasil kegiatan empirik dan kegiatan analitis yang dilakukan oleh para ilmuwan selama berabad-abad. Bentuk Ilmu Pengetahuan Alam sebagai produk, menurut Iskandar (1997, p. 2) adalah: "Fakta-fakta, konsep-konsep, prinsipprinsip, dan teori-teori IImu Pengetahuan Alam".

Selanjutnya fakta dalam IImu Pengetahuan Alam adalah pernyataanpernyataan tentang benda-benda yang benar-benar ada, atau peristiwa-peristiwa yang betul-betul terjadi dan sudah dikonfirmasi secara objektif. Sedangkan konsep IImu Pengetahuan Alam adalah suatu ide yang mempersatukan faktafakta Ilmu Pengetahuan Alam yang merupakan penghubung antara faktafakta yang ada hubungannya. Prinsip IImu Pengetahuan Alam adalah generasi tentang hubungan di antara konsepkonsep Ilmu Pengetahuan Alam. Kemudian teori ilmiah merupakan kerangka yang lebih luas dari fakta-fakta, konsep-konsep, dan prinsip-prinsip yang saling berhubungan. Suatu teori merupakan model atau gambaran yang dibuat oleh ilmuwan untuk menjelaskan gejala alam.

\section{Ilmu Pengetahuan Alam sebagai Proses}

Dalam memahami Ilmu Pengetahuan Alam tidak hanya mengetahui fakta-fakta dalam IImu Pengetahuan Alam, tetapi juga perlu memahami proses Ilmu Pengetahuan Alam. Hal ini didasarkan pada pendapat Iskandar (1997), bahwa perlu memahami bagaimana mengumpulkan fakta-fakta dan memahami bagaimana menghubungkan fakta-fakta untuk menginterpretasikannya para ilmuwan menggunakan berbagai prosedur empirik dan prosedur analitis dalam usaha mereka untuk memahami alam semesta ini. Prosedur-prosedur tersebut disebut proses ilmiah atau proses IImu Pengetahuan Alam.

Keterampilan proses IImu Pengetahuan Alam, merupakan keterampilan yang dilakukan oleh para ilmuwan, di antaranya adalah mengamati, megukur, menarik kesimpulan, mengendalikan variabel, merumuskan hipotesis, membuat grafik dan tabel data, membuat definisi operasional, dan melakukan eksperimen. Di dalam IImu Pengetahuan Alam, pengertian mengamati berdasarkan pendapat Iskandar (1997, p. 4), adalah: "Proses mengumpulkan informasi menggunakan semua alat pengindra atau mempergunakan instrumen untuk membantu alat pengindra". Selanjutnya dari proses mengamati dapat menarik simpulan-simpulan setelah melakukan observasi dan berdasarkan pengetahuan yang dimiliki sebelumnya setelah diadakan pengamatan terlebih dahulu.

Dengan demikian, di dalam keterampilan IImu Pengetahuan Alam pun perlu melakukan penelitian atau penyelidikan 
kemudian menginterpretasikan hasil penelitian dan mengkomunikasikannya kepada masyarakat untuk dijadikan ilmu pengetahuan yang dapat bermanfaat yang selanjutnya dapat dirumuskan ke dalam hipotesis untuk menyusun suatu pernyataan berdasarkan alasan-alasan atau pengetahuan, yang merupakan jawaban sementara untuk masalah yang dijadikan pengamatan sehingga dapat diinterpretasikan melalui data dengan menganalisis data tersebut setelah diperoleh dan disusun dengan cara menentukan pola keterhubungan data secara keseluruhan.

\section{Pengertian Model Pembelajaran Kooperatif Tipe STAD}

Pembelajaran kooperatif yang digunakan adalah tipe STAD. Menurut Trianto (2007, p. 52) pembelajaran kooperatif tipe STAD ini merupakan salah satu tipe model pembelajaran kooperatif dengan menggunakan kelompok-kolompok kecil dengan jumlah anggota tiap kelompok 4 sampai dengan 5 orang siswa secara hetorgen. Diawali dengan penyampaian tujuan pembelajaran, penyampaian materi, kegiatan kelompok, kuis, dan penghargaan kelompok. Menurut Muslimin, dkk. (2000, p. 17), landasan teori tentang STAD dengan belajar berdasarkan pengalaman adalah "... siswa lebih memiliki kemungkinan menggunakan tingkat berpikir yang lebih tinggi selama dan setelah diskusi dalam kelompok kooperatif daripada mereka bekerja secara individual. Jadi materi yang dipelajari siswa akan melekat untuk periode waktu yang lebih lama".

Selanjutnya, Slavin (dalam Muslimin, dkk., p. 26) mengemukakan tentang model pembelajaran kooperatif tipe STAD bahwa:

STAD menetapkan siswa dalam tim belajar beranggotakan empat orang yang merupakan campuran menurut tingkat prestasi, jenis kelamin, dan suku. Guru menyajikan pelajaran dan kemudian siswa bekerja di dalam tim mereka untuk memastikan bahwa seluruh anggota tim telah menguasai pelajaran tersebut. Akhirnya, seluruh siswa dikenai kuis tentang materi itu. Pada waktu kuis ini, mereka tidak saling membantu. Poin tiap anggota tim dijumlahkan untuk mendapatkan skor tim, dan tim yang mencapai kriteria tertentu dapat diberi penghargaan.

Jadi, tipe STAD merupakan salah satu model pembelajaran kooperatif yang menggabungkan latar belakang siswa dalam kolompok dengan jumlah anggota tiap kelompok 4-5 orang.

\section{Langkah-Langkah Model Pembelajaran Kooperatif Tipe STAD}

Pembelajaran kooperatif dalam suatu kelompok kecil siswa yang bekerja sebagai sentral tim untuk menyelesaikan masalah, menyelesaikan suatu tugas atau mengerjakan sesuatu untuk mencapai tujuan bersama lainnya (Suherman, dkk. 2003, p. 260). STAD adalah salah satu tipe model pembelajaran kooperatif yang terdiri dari kelompok belajar heterogen beranggotakan 4-5 orang siswa dan setiap siswa saling bekerja sama, berdiskusi dalam menyelesaikan tugas dan 
memahami bahan pelajaran yang diberikan. Ada beberapa tipe model pembelajaran kooperatif, salah satunya adalah STAD. STAD merupakan salah satu tipe model pembelajaran kooperatif yang paling sederhana, dan merupakan pendekatan yang baik untuk guru yang baru memulai menerapkan model pembelajaran kooperatif dalam kelas (Wijayanti, 2002, p. 2).

Secara rinci langkah-langkah model pembelajaran kooperatif tipe STAD ini didasarkan pada langkah-langkah pembelajaran kooperatif yang terdiri atas enam langkah atau fase. Fase-fase dalam pembelajaran ini seperti dalam tabel berikut ini.

Tabel 1. Fase-Fase Model Pembelajaran Kooperatif Tipe STAD

\begin{tabular}{|l|l|}
\hline \multicolumn{1}{|c|}{ Fase } & \multicolumn{1}{c|}{ Kegiatan Guru } \\
Fase 1 \\
$\begin{array}{l}\text { Menyampaikan } \\
\text { tujuan dan } \\
\text { memotivasi siswa }\end{array}$ & $\begin{array}{l}\text { Menyampaikan nsemua } \\
\text { tujuan pelajaran yang } \\
\text { ingin dicapai pada } \\
\text { pelajaran tersebut dan } \\
\text { memotivasi siswa }\end{array}$ \\
\hline $\begin{array}{l}\text { Fase 2 } \\
\text { Menyajikan/ } \\
\text { menyampaikan } \\
\text { informasi }\end{array}$ & $\begin{array}{l}\text { Menyajikan informasi } \\
\text { kepada siswa dengan } \\
\text { jalan mendemonstrasikan } \\
\text { atau lewat bahan } \\
\text { bacaan }\end{array}$ \\
\hline $\begin{array}{l}\text { Fase 3 } \\
\text { Mengorganisasi- } \\
\text { kan siswa dalam } \\
\text { kelompok- } \\
\text { kelompok belajar }\end{array}$ & $\begin{array}{l}\text { Menjelaskan kepada } \\
\text { siswa bagaiamana } \\
\text { caranya membentuk } \\
\text { kelompok belajar dan } \\
\text { membantu setiap } \\
\text { kelompok agar } \\
\text { melakukan transisi secara } \\
\text { efisien }\end{array}$ \\
\hline $\begin{array}{l}\text { Fase 4 } \\
\text { Membimbing } \\
\text { kelompok bekerja } \\
\text { dan belajar }\end{array}$ & $\begin{array}{l}\text { kelompoking kelompok- } \\
\text { saat mereka } \\
\text { mengerjakan tugas } \\
\text { mereka }\end{array}$ \\
\hline $\begin{array}{l}\text { Fase 5 } \\
\text { Evaluasi }\end{array}$ & $\begin{array}{l}\text { Mengevaluasi hasil } \\
\text { belajar tentang materi } \\
\text { yang diajarakan atau } \\
\text { masing-masing kelompok }\end{array}$ \\
\hline
\end{tabular}

\begin{tabular}{|c|c|}
\hline & $\begin{array}{l}\text { mempresentasikan hasil } \\
\text { kerjanya }\end{array}$ \\
\hline $\begin{array}{l}\text { Fase } 6 \\
\text { Memberikan } \\
\text { penghargaan }\end{array}$ & $\begin{array}{l}\text { Mencari cara-cara untuk } \\
\text { menghargai baik upaya } \\
\text { maupun hasil belajar } \\
\text { individu atau kelompok }\end{array}$ \\
\hline
\end{tabular}

(Sumber: Ibrahim dalam Trianto, 2007, p. 54)

\section{METODE}

\section{Lokasi Pelaksanaan}

Lokasi perbaikan dilaksanakan di kelas IV pada semester I di SD Negeri Jatiroke I Kecamatan Jatinangor Kabupaten sumedang UPTD TK/SD dan PNF Kecamatan Jatinangor Kabupaten Sumedang yang berjumlah 18 orang dengan rincian 8 orang siswa laki-laki dan 10 orang siswa perempuan. Pelaksanaan penelitian tindakan kelas ini, peneliti mendapat bantuan dari rekan-rekan selaku teman sejawat dan membantu peneliti dalam menyusun laporan penelitian serta memberi masukanmasukan kepada peneliti melaksanakan penelitian tindakan kelas.

\section{Waktu Pelaksanaan}

Penelitian tindakan kelas ini dilaksanakan selama satu bulan dengan jumlah pertemuan sebanyak dua kali. Adapun pelaksanaan penelitian tindakan kelas, dalam setiap pertemuan adalah sebagai berikut:

Tabel 2. Jadwal Pelaksanaan Penelitian Tindakan Kelas

\begin{tabular}{|l|c|c|c}
\hline Pertemuan ke & $\begin{array}{c}\text { Mata } \\
\text { Pelajaran }\end{array}$ & Siklus & Jam \\
\hline Satu & IPA & I & $\begin{array}{c}07.00- \\
08.10\end{array}$ \\
\hline Dua & IPA & $\|$ & $\begin{array}{c}10.00- \\
11.10\end{array}$ \\
\hline
\end{tabular}




\section{Karakteristik Siswa}

Pada dasarnya siswa kelas IV berada pada taraf ekonomi menengah ke bawah. Rata-rata penghasilan orang tua siswa mencapai Rp. 1.500 .000 > per bulan. Pekerjaan orang tua mereka sebagian besar bekerja sebagai karyawan di sebuah pabrik. Sebagian lagi bekerja sebagai petani dan berwiraswasta. Kemampuan anak dalam mengikuti pelajaran secara akademis memiliki kemampuan dan kreativitas yang baik terhadap proses pembelajaran. Hal ini terbukti mereka secara antusias datang lebih awal, walaupun masuk sekolah pukul 07.00 WIB tetapi pukul 06.30 WIB sudah banyak siswa yang jajan, piket, main dan mengerjakan PR sebelum masuk ke kelas.

\section{Rancangan Penelitian}

Rancangan atau prosedur penelitian mengacu pada model penelitian tindakan kelas Kemmis \& Taggart (Wiriaatmadja, 2005), dengan langkahlangkah siklus sebagai berikut: 1) perencanaan, 2) pelaksanaan, 3) observasi, dan 4) refleksi.

\section{HASIL}

\section{Hasil Pra-Siklus}

Data awal penelitian diperoleh melalui studi awal yang dilaksanakan di SD Negeri Jatiroke I Kecamatan Jatinangor Kabupaten Sumedang. Dari data awal pembelajaran IPA tentang mengidentifikasi jenis makanan hewan, diketahui rata-rata hasil belajar siswa masih jauh dari harapan bahkan banyak nilai siswa yang di bawah kriteria ketuntasan minimal $(K K M=70)$, ini menunjukkan pemahaman siswa mengenai pembelajaran IPA tentang mengidentifikasi jenis makanan hewan masih kurang. Hal tersebut di tunjukan dengan pemerolehan nilai siswa dari 18 siswa hanya 6 atau $33 \%$ siswa yang mendapatkan nilai di atas kriteria ketuntasan minimal. Adapun nilai perolehan siswa pada data awal adalah sebagai berikut.

Tabel 3. Daftar Nilai Sebelum Penelitian Tindakan Kelas

\begin{tabular}{|c|c|c|c|c|}
\hline No & $\begin{array}{l}\text { Nama } \\
\text { Siswa }\end{array}$ & $\begin{array}{c}\text { Hasil } \\
\text { Belajar }\end{array}$ & Tuntas & $\begin{array}{c}\text { Tidak } \\
\text { Tuntas }\end{array}$ \\
\hline 1 & $\begin{array}{l}\text { Yanti } \\
\text { Marlina }\end{array}$ & 40 & & $\sqrt{ }$ \\
\hline 2 & $\begin{array}{l}\text { Yayang } \\
\text { Tomi A }\end{array}$ & 50 & & $\sqrt{ }$ \\
\hline 3 & $\begin{array}{l}\text { Eko } \\
\text { Sutriono }\end{array}$ & 30 & & $\sqrt{ }$ \\
\hline 4 & $\begin{array}{l}\text { Agustin } \\
\text { Andriani }\end{array}$ & 40 & & $\sqrt{ }$ \\
\hline 5 & $\begin{array}{l}\text { Andi } \\
\text { Gunawan }\end{array}$ & 70 & $\sqrt{ }$ & \\
\hline 6 & $\begin{array}{l}\text { Eljam Putra } \\
\mathrm{N}\end{array}$ & 60 & & $\sqrt{ }$ \\
\hline 7 & $\begin{array}{l}\text { Rizki } \\
\text { Nugraha }\end{array}$ & 70 & $\sqrt{ }$ & \\
\hline 8 & $\begin{array}{l}\text { Desi } \\
\text { Firgiani }\end{array}$ & 30 & & $\sqrt{ }$ \\
\hline 9 & $\begin{array}{l}\text { Muh } \\
\text { Ramdan K }\end{array}$ & 60 & $\sqrt{ }$ & \\
\hline 10 & $\begin{array}{l}\text { Ari } \\
\text { Ramdani }\end{array}$ & 80 & $\sqrt{ }$ & \\
\hline 11 & $\begin{array}{l}\text { Yulia Tri } \\
\text { Andita }\end{array}$ & 70 & $\sqrt{ }$ & \\
\hline 12 & $\begin{array}{l}\text { Kharina } \\
\text { Ruswandi }\end{array}$ & 60 & & $\sqrt{ }$ \\
\hline 13 & $\begin{array}{l}\text { Bernar } \\
\text { Andiat P }\end{array}$ & 50 & & $\sqrt{ }$ \\
\hline 14 & $\begin{array}{l}\text { Linda } \\
\text { Krismayanti }\end{array}$ & 60 & & $\sqrt{ }$ \\
\hline 15 & $\begin{array}{l}\text { Muhamad } \\
\text { Sopian }\end{array}$ & 70 & $\sqrt{ }$ & \\
\hline 16 & Ridwan N & 40 & & $\sqrt{ }$ \\
\hline 17 & $\begin{array}{l}\text { Yanti } \\
\text { Marlina }\end{array}$ & 50 & & $\sqrt{ }$ \\
\hline 18 & $\begin{array}{l}\text { Yayang } \\
\text { Tomi A }\end{array}$ & 50 & & $\sqrt{ }$ \\
\hline
\end{tabular}




\begin{tabular}{|c|c|c|c|}
\hline JUMLAH & 980 & 6 & 12 \\
\hline RATA-RATA & 54,44 & & \\
\hline PERSENTASE (\%) & & $33 \%$ & \\
\hline
\end{tabular}

Keterangan:

Kriteria Ketuntasan Minimal: 70

Jumlah Siswa Tuntas: 6 Siswa

Jumlah Siswa Tidak tuntas: 12 Siswa

Klasikal: 33 \% (Tidak Tuntas)

\section{Hasil Siklus 1}

Pelaksanaan siklus 1 dilaksanakan pada jam pelajaran kedua. Pelaksanaan dilakukan dalam satu kali pertemuan dengan alokasi waktu $2 \times 35$ menit. Lebih lanjut, untuk memudahkan guru dalam melaksanakan pembelajaran maka disusun skenario pembelajaran sebagai berikut.

Tahap menyampaikan tujuan dan memotivasi siswa, siswa diarahkan pada situasi yang kondusif. Guru memeriksa kehadiran siswa, kemudian meminta siswa untuk berdo'a dan menyiapkan alat-alat pembelajaran. Guru membuka pelajaran dengan menginformasikan tentang kegiatan yang akan dilaksanakan, tujuan yang harus dicapai serta mengenalkan kegiatan pembelajaran mengidentifikasi jenis makan hewan dengan menerapkan model pembelajaran kooperatif tipe STAD. Menggali informasi tentang mengidentifikasi jenis makan hewan yang ditemukan siswa dalam sehari-hari dengan mengajukan pertanyaan-pertanyaan yang berkaitan dengan materi. Kemudian mengadakan apersepsi dengan mengajukan beberapa pertanyaan.
Tahap menyajikan atau menyampaikan informasi, guru memberikan informasi mengidentifikasi jenis makan hewan, seperti sapi, harimau, banteng, dan lainlain, sambil memberikan pertanyanpertanyaan yang mengarah pada mengidentifikasi jenis makan hewan. Dalam kelompok siswa mengamati jenis makanan hewan yang dilakukan oleh guru.

Tahap mengorganisasikan siswa dalam kelompok-kelompok belajar, siswa dalam kelompoknya melakukan diskusi untuk mengidentifikasi jenis makan hewan, mencatat jenis-jenis hewan, dan menggolongkan hewan menurut jenis makanannya. Siswa berdiskusi dalam kelompok untuk menjawab pertanyaanpertanyaan di dalam LKS.

Tahap membimbing kelompok bekerja dan belajar, guru membimbing siswa baik secara individu maupun kelompok dalam pemahaman materi, sikap dan perilaku siswa dalam diskusi kelompok. Siswa mengerjakan LKS tentang mengidentifikasi jenis makan hewan dan memberikan solusi. Perwakilan setiap kelompok menyampaikan hasil diskusi kelompok di depan kelas. Tiap-tiap kelompok menanggapi, mengomentari dan menyamakan persepsi tentang mengidentifikasi jenis makan hewan dan memberikan solusi dalam diskusi kelas.

Tahap evaluasi/kuis, guru menilai hasil kerja siswa dalam kelompok dan 
Ocih Sukaesih, Penerapan Model Pembelajaran Kooperatif...

mengumumkannya di depan kelas. Guru membagikan lembar evaluasi pada tiap siswa. Guru menilai hasil kerja tiap siswa, hasil ini merupakan nilai akhir kemampuan siswa serta untuk mengetahui pengaruh belajar kelompok dengan model pembelajaran kooperatif tipe STAD pada tingkat kemampuan siswa dalam memahami mengidentifikasi jenis makanan hewan.

Tahap memberikan penghargaan, guru melakukan cara-cara untuk menghargai hasil karya siswa dalam mengidentifikasi jenis makan hewan dan memberikan solusinya dengan pemberian penghargaan pada tiap kelompok dan individu.

Adapun prestasi belajar siswa dari pembelajaran mengidentifikasi jenis makan hewan pada siklus I dapat dilihat dalam tabel di bawah ini.

Tabel 4. Daftar Nilai Penelitian Tindakan Kelas Siklus 1

\begin{tabular}{|c|l|c|c|c|}
\hline No & Nama Siswa & $\begin{array}{c}\text { Hasil } \\
\text { Belajar }\end{array}$ & Tuntas & $\begin{array}{c}\text { Tidak } \\
\text { Tuntas }\end{array}$ \\
\hline 1 & Yanti Marlina & 70 & $\sqrt{ }$ & \\
\hline 2 & $\begin{array}{l}\text { Yayang Tomi } \\
\text { A }\end{array}$ & 80 & $\sqrt{ }$ & \\
\hline 3 & Eko Sutriono & 50 & & $\sqrt{ }$ \\
\hline 4 & $\begin{array}{l}\text { Agustin } \\
\text { Andriani }\end{array}$ & 60 & & $\sqrt{ }$ \\
\hline 5 & $\begin{array}{l}\text { Andi } \\
\text { Gunawan }\end{array}$ & 70 & $\sqrt{ }$ & \\
\hline 6 & Eljam Putra N & 70 & $\sqrt{ }$ & \\
\hline 7 & Rizki Nugraha & 90 & $\sqrt{ }$ & \\
\hline 8 & Desi Firgiani & 50 & & $\sqrt{ }$ \\
\hline 9 & $\begin{array}{l}\text { Muh Ramdan } \\
\text { K }\end{array}$ & 70 & $\sqrt{ }$ & \\
\hline 10 & Ari Ramdani & 80 & $\sqrt{ }$ & \\
\hline 11 & Yulia Tri Andita & 70 & $\sqrt{ }$ & \\
\hline 12 & $\begin{array}{l}\text { Kharina } \\
\text { Ruswandi }\end{array}$ & 60 & & $\sqrt{ }$ \\
\hline
\end{tabular}

\begin{tabular}{|c|c|c|c|c|}
\hline 13 & $\begin{array}{l}\text { Bernar Andiat } \\
\text { P }\end{array}$ & 50 & & $\sqrt{ }$ \\
\hline 14 & $\begin{array}{l}\text { Linda } \\
\text { Krismayanti }\end{array}$ & 60 & & $\sqrt{ }$ \\
\hline 15 & $\begin{array}{l}\text { Muhamad } \\
\text { Sopian }\end{array}$ & 70 & $\sqrt{ }$ & \\
\hline 16 & Ridwan N & 40 & & $\sqrt{ }$ \\
\hline 17 & Yanti Marlina & 80 & $\sqrt{ }$ & \\
\hline 18 & $\begin{array}{l}\text { Yayang Tomi } \\
\text { A }\end{array}$ & 50 & & $\sqrt{ }$ \\
\hline \multicolumn{2}{|r|}{ JUMLAH } & 1170 & 10 & 8 \\
\hline \multicolumn{2}{|r|}{ RATA-RATA } & 65 & & \\
\hline \multicolumn{2}{|r|}{ PERSENTASE (\%) } & & $55 \%$ & \\
\hline
\end{tabular}

Keterangan:

Kriteria Ketuntasan Minimal: 70

Jumlah Siswa Tuntas: 10 Siswa

Jumlah Siswa Tidak Tuntas: 8 Siswa

Klasikal: 55 \% (Tidak Tuntas)

\section{Hasil Siklus 2}

Pelaksanaan siklus II tidak jauh berbeda pelaksanaan tindakannya dengan siklus I. Pelaksanaan dilakukan dalam satu kali pertemuan dengan alokasi waktu $2 \times 35$ menit. Rencana penelitian tindakan kelas siklus 2 dapat dilihat di bawah ini.

Tahap menyampaikan tujuan dan memotivasi siswa, siswa diarahkan pada situasi yang kondusif. Guru memeriksa kehadiran siswa, kemudian meminta siswa untuk berdo'a dan menyiapkan alat-alat pembelajaran. Guru membuka pelajaran dengan menginformasikan tentang kegiatan yang akan dilaksanakan, tujuan yang harus dicapai serta mengenalkan kegiatan pembelajaran mengidentifikasi jenis makan hewan dengan menerapkan model pembelajaran kooperatif tipe STAD. Menggali informasi tentang mengidentifikasi jenis makan hewan yang ditemukan siswa dalam sehari-hari dengan 
mengajukan pertanyaan-pertanyaan yang berkaitan dengan materi. Kemudian mengadakan apersepsi dengan mengajukan beberapa pertanyaan.

Tahap menyajikan atau menyampaikan informasi, guru memberikan informasi mengidentifikasi jenis makan hewan, seperti sapi, harimau, banteng, dan lainlain, sambil memberikan pertanyanpertanyaan yang mengarah pada mengidentifikasi jenis makan hewan. Dalam kelompok siswa mengamati jenis makanan hewan yang dilakukan oleh guru.

Tahap mengorganisasikan siswa dalam kelompok-kelompok belajar, siswa dalam kelompoknya melakukan diskusi untuk mengidentifikasi jenis makan hewan, mencatat jenis-jenis hewan, dan menggolongkan hewan menurut jenis makanannya. Siswa berdiskusi dalam kelompok untuk menjawab pertanyaanpertanyaan di dalam LKS.

Tahap membimbing kelompok bekerja dan belajar, guru membimbing siswa baik secara individu maupun kelompok dalam pemahaman materi, sikap dan perilaku siswa dalam diskusi kelompok. Siswa mengerjakan LKS tentang mengidentifikasi jenis makan hewan dan memberikan solusi. Perwakilan setiap kelompok menyampaikan hasil diskusi kelompok di depan kelas. Tiap-tiap kelompok menanggapi, mengomentari dan menyamakan persepsi tentang mengidentifikasi jenis makan hewan dan memberikan solusi dalam diskusi kelas.

Tahap evaluasi/kuis, guru menilai hasil kerja siswa dalam kelompok dan mengumumkannya di depan kelas. Guru membagikan lembar evaluasi pada tiap siswa. Guru menilai hasil kerja tiap siswa, hasil ini merupakan nilai akhir kemampuan siswa serta untuk mengetahui pengaruh belajar kelompok dengan model pembelajaran kooperatif tipe STAD pada tingkat kemampuan siswa dalam memahami mengidentifikasi jenis makanan hewan.

Tahap memberikan penghargaan, guru melakukan cara-cara untuk menghargai hasil karya siswa dalam mengidentifikasi jenis makan hewan dan memberikan solusinya dengan pemberian penghargaan pada tiap kelompok dan individu.

Berdasarakan hasil pengolahan data dari penelitian tindakan kelas siklus I, maka penelitian tindakan kelas pada siklus ॥ difokuskan pada:

1. ketepatan penggunaan media dan metode pembelajaran,

2. upaya guru dalam menetapkan variasi metode pembelajaran,

3. upaya guru dalam membangkitkan aktivitas, motivasi dan perhatian siswa,

4. upaya guru dalam membimbing siswa dalam melakukan langkah-langkah model pembelajaran kooperatif tipe STAD. 
Berikut ini prestasi hasil belajar siswa dalam hasil observasi penelitian tindakan kelas mengidentifikasi jenis makan hewandapat dilihat pada tabel di bawah ini.

Tabel 5. Daftar Nilai Penelitian Tindakan

Kelas Siklus 2

\begin{tabular}{|c|c|c|c|c|}
\hline No & Nama Siswa & $\begin{array}{c}\text { Hasil } \\
\text { Belajar }\end{array}$ & Tuntas & $\begin{array}{l}\text { Tidak } \\
\text { Tuntas }\end{array}$ \\
\hline 1 & $\begin{array}{l}\text { Yanti } \\
\text { Marlina }\end{array}$ & 80 & $\sqrt{ }$ & \\
\hline 2 & $\begin{array}{l}\text { Yayang } \\
\text { Tomi A }\end{array}$ & 90 & $\sqrt{ }$ & \\
\hline 3 & Eko Sutriono & 70 & $\sqrt{ }$ & \\
\hline 4 & $\begin{array}{l}\text { Agustin } \\
\text { Andriani }\end{array}$ & 90 & $\sqrt{ }$ & \\
\hline 5 & $\begin{array}{l}\text { Andi } \\
\text { Gunawan }\end{array}$ & 100 & $\sqrt{ }$ & \\
\hline 6 & $\begin{array}{l}\text { Eljam Putra } \\
\mathrm{N}\end{array}$ & 90 & $\sqrt{ }$ & \\
\hline 7 & $\begin{array}{l}\text { Rizki } \\
\text { Nugraha }\end{array}$ & 100 & $\sqrt{ }$ & \\
\hline 8 & Desi Firgiani & 80 & $\sqrt{ }$ & \\
\hline 9 & $\begin{array}{l}\text { Muh } \\
\text { Ramdan K }\end{array}$ & 90 & $\sqrt{ }$ & \\
\hline 10 & Ari Ramdani & 100 & $\sqrt{ }$ & \\
\hline 11 & $\begin{array}{l}\text { Yulia Tri } \\
\text { Andita }\end{array}$ & 100 & $\sqrt{ }$ & \\
\hline 12 & $\begin{array}{l}\text { Kharina } \\
\text { Ruswandi }\end{array}$ & 90 & $\sqrt{ }$ & \\
\hline 13 & $\begin{array}{l}\text { Bernar } \\
\text { Andiat P }\end{array}$ & 70 & $\sqrt{ }$ & \\
\hline 14 & $\begin{array}{l}\text { Linda } \\
\text { Krismayanti }\end{array}$ & 80 & $\sqrt{ }$ & \\
\hline 15 & $\begin{array}{l}\text { Muhamad } \\
\text { Sopian }\end{array}$ & 100 & $\sqrt{ }$ & \\
\hline 16 & Ridwan N & 80 & $\sqrt{ }$ & \\
\hline 17 & $\begin{array}{l}\text { Yanti } \\
\text { Marlina }\end{array}$ & 100 & $\sqrt{ }$ & \\
\hline 18 & $\begin{array}{l}\text { Yayang } \\
\text { Tomi A }\end{array}$ & 80 & $\sqrt{ }$ & \\
\hline & JUMLAH & 1590 & 18 & - \\
\hline \multicolumn{2}{|r|}{ RATA-RATA } & 88,33 & & \\
\hline \multicolumn{2}{|c|}{ PERSENTASE (\%) } & & $100 \%$ & \\
\hline
\end{tabular}

Keterangan :

Kriteria Ketuntasan Minimal: 70

Jumlah Siswa Tuntas: 18 Siswa

Jumlah Siswa Tidak tuntas: Tidak Ada

Klasikal: 100 \% (Tuntas)

Pada siklus 2 terlihat adanya peningkatan yang cukup berarti dalam pembelajaran pembelajaran mengidentifikasi jenis makanan hewan. Semua siswa Kelas IV SD Negeri Jatiroke I yang berjumlah 21 orang sudah mendapatkan nilai di atas 70 atau $100 \%$ dengan rata-rata kelas 88,33 .

Gambaran kemajuan hasil belajar siswa, di bawah ini disajikan perbandingan hasil belajar siswa dari data awal, Siklus 1, dan Siklus 2 dilengkapi grafik kemajuan hasil belajarnya adalah sebagai berikut.

\section{Tabel 6. Perbandingan Hasil Belajar Siswa} dari Data Awal, Siklus 1 dan Siklus 2

\begin{tabular}{|c|c|c|c|c|}
\hline No & Nama Siswa & $\begin{array}{l}\text { Data } \\
\text { Awal }\end{array}$ & $\begin{array}{c}\text { Siklus } \\
1\end{array}$ & $\begin{array}{c}\text { Siklus } \\
2\end{array}$ \\
\hline 1 & Yanti Marlina & 40 & 70 & 80 \\
\hline 2 & Yayang Tomi A & 50 & 80 & 90 \\
\hline 3 & Eko Sutriono & 30 & 50 & 70 \\
\hline 4 & $\begin{array}{l}\text { Agustin } \\
\text { Andriani }\end{array}$ & 40 & 60 & 90 \\
\hline 5 & $\begin{array}{l}\text { Andi } \\
\text { Gunawan }\end{array}$ & 70 & 70 & 100 \\
\hline 6 & Eljam Putra N & 60 & 70 & 90 \\
\hline 7 & Rizki Nugraha & 70 & 90 & 100 \\
\hline 8 & Desi Firgiani & 30 & 50 & 80 \\
\hline 9 & $\begin{array}{l}\text { Muh Ramdan } \\
\text { K }\end{array}$ & 60 & 70 & 90 \\
\hline 10 & Ari Ramdani & 80 & 80 & 100 \\
\hline 11 & Yulia Tri Andita & 70 & 70 & 100 \\
\hline 12 & $\begin{array}{l}\text { Kharina } \\
\text { Ruswandi }\end{array}$ & 60 & 60 & 90 \\
\hline 13 & $\begin{array}{l}\text { Bernar Andiat } \\
\text { P }\end{array}$ & 50 & 50 & 70 \\
\hline 14 & $\begin{array}{l}\text { Linda } \\
\text { Krismayanti }\end{array}$ & 60 & 60 & 80 \\
\hline 15 & $\begin{array}{l}\text { Muhamad } \\
\text { Sopian }\end{array}$ & 70 & 70 & 100 \\
\hline 16 & Ridwan N & 40 & 40 & 80 \\
\hline 17 & Yanti Marlina & 50 & 80 & 100 \\
\hline 18 & Yayang Tomi A & 50 & 50 & 80 \\
\hline \multicolumn{2}{|r|}{ JUMLAH } & 980 & 1170 & 1590 \\
\hline \multicolumn{2}{|r|}{ RATA-RATA } & 54,44 & 65 & 88,33 \\
\hline \multicolumn{2}{|c|}{ PERSENTASE (\%) } & $33 \%$ & $55 \%$ & $\begin{array}{c}100 \\
\%\end{array}$ \\
\hline
\end{tabular}

Bila dilihat dalam diagram maka akan terlihat peningkatan hasil belajar siswa seperti di bawah ini. 


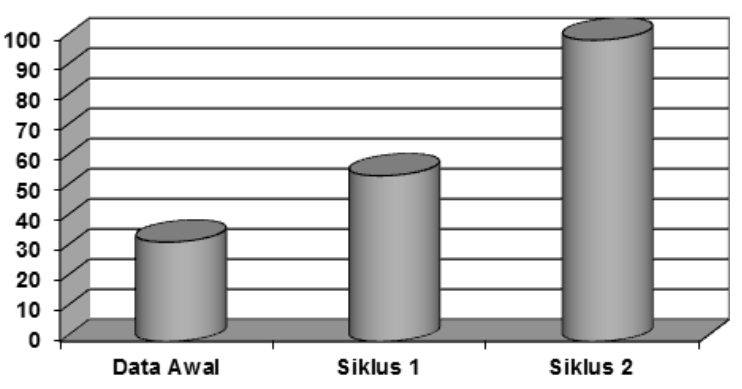

Diagram 1. Hasil Belajar Siswa dari Data Awal, Siklus 1 dan Siklus 2

\section{PEMBAHASAN}

Berdasarkan hasil observasi yang dilakukan oleh peneliti pada siswa Kelas IV SD Negeri Jatiroke I dalam pembelajaran mengidentifikasi jenis makanan hewan adalah sebagai berikut.

Peningkatan proses kinerja guru yang terjadi pada siklus I adalah guru mulai menerapkan model pembelajaran kooperatif tipe STAD dengan konsep bahwa pembelajaran kooperatif merupakan strategi belajar-mengajar yang menekankan pada sikap atau perilaku anak dalam mengerjakan suatu kegiatan secara bersama-sama dengan berdiskusi dan saling membantu satu sama lainnya dalam suatu kelompok kecil (Saputra, 2004, p. 44). Jika, dibandingkan kinerja guru pada data awal dengan siklus I sangat berbeda, karena guru dapat memanfaatkan kelebihan pembelajaran kooperatif dengan tipe STAD. Sebagaimana pandangan Trianto (2007, p. 52), bahwa salah satu tipe model pembelajaran kooperatif dengan menggunakan kelompok-kolompok kecil dengan jumlah anggota tiap kelompok 4 sampai 5 orang siswa secara hetorgen yang diawali dengan penyampaian tujuan pembelajaran, penyampaian materi, kegiatan kelompok, kuis, dan penghargaan kelompok.

Kelebihan model pembelajaran kooperatif tipe STAD tersebut dilakukan oleh guru, sehingga aktivitasnya dapat mengenalkan kegiatan pembelajaran mengidentifikasi jenis makanan hewan. Namun, terlepas dari kelebihan yang terjadi pada dari siklus I tersebut, ada juga kekurangan yang dialami oleh guru, karena pada saat pembelajaran berlangsung guru kurang memberikan perhatian kepada seluruh siswa, sehingga dampaknya siswa menjadi ribut dan pada waktu langkah terakhir pada pola model pembelajaran kooperatif tipe STAD guru kurang jelas dan kurang adil dalam memberikan bentuk penghargaan, sehingga adanya kecemburuan dari pihak kelompok maupun individu yang perlakukan kurang adil. Padahal dalam model pembelajaran kooperatif tipe STAD tahap akhir menurut Salvin (dalam Muslimin, dkk., 2000, p. 26) adalah "... poin tiap anggota tim dijumlahkan untuk mendapatkan skor tim, dan tim yang mencapai kriteria tertentu dapat diberi penghargaan."

Peningkatan proses kinerja guru yang terjadi pada siklus II adalah guru tetap menerapkan pola model pembelajaran kooperatif tipe STAD dengan mempersiapkan materi, LKS, soal kuis dan metode pembelajaran, pembagian 
Ocih Sukaesih, Penerapan Model Pembelajaran Kooperatif...

kelompok diatur berdasarkan skor awal, masing-masing kelompok terdiri dari tiga orang dalam satu kelompok dengan prestasi yang bervariasi, jenis kelamin dan ras yang berbeda seperti pada siklus I, seperti yang dikemukakan oleh Slavin (dalam Juwita, 2004, p. 27) bahwa, "Guru menjelaskan bahwa tugas tim adalah membantu anggota untuk menguasai materi dan mempersiapkan kuis serta setiap individu akan berpengaruh besar terhadap kelompok". Begitu juga dalam langkah terakhir yang tadinya dalam siklus I ada siswa atau kelompok yang dirugikan, tapi pada siklus II guru memberikan penjelasan arti atau makna dari bentuk penghargaan, sehingga hampir semua siswa dapat merasakan manfaat dari penghargaan dari guru, karena dapat diberitahukan kepada orang tuanya bahwa dirinya dapat penghargaan.

Kelebihan pada siklus II, bahwa guru sudah mulai paham dan menyadari tahapan model pembelajaran kooperatif tipe STAD dengan memberikan perhatian dengan serius pada semua siswa dan memberi penghargaan yang adil sehingga dirasakan oleh siswa dalam kelompok dan individu. Kelebihan tersebut didasarkan pada karakteristik model pembelajaran kooperatif, yang menurut (Suherman, dkk., 2001), antara lain:

1. Individual accountability, bahwa setiap individu di dalam kelompok punya tanggung jawab dalam menyelesaikan masalah yang dihadapi oleh kelompok, sehingga keberhasilan kelompok sangat ditentukan oleh tanggung jawab dan peranserta setiap anggotanya.

2. Social skills, meliputi seluruh hidup sosial, kepekaan sosial, menumbuhkan pengekangan diri demi kepentingan kelompok. Keterampilan jenis ini mengajarkan siswa untuk belajar memberi dan menerima, mengambil dan menerima tanggung jawab, menghormati hak orang lain dan membentuk kesadaran sosial.

3. Positive interdependence, adalah sifat saling membutuhkan atau bergantung antara yang satu terhadap yang lain di dalam kelompok secara positif.

4. Group processing, yakni proses pemerolehan jawaban permasalahan dikerjakan oleh kelompok secara bersama-sama.

Adapun kekurangan proses kinerja guru yang terjadi pada siklus 1 dalam langkah evaluasi, guru kurang memperhatikan aspek penilaian pembelajaran IPA di SD, tanpa memperhatikan karakteristik mata pelajaran IPA itu sendiri.

\section{SIMPULAN}

Berdasarkan hasil penerapan model pembelajaran kooperatif tipe STAD dalam meningkatkan pemahaman siswa terhadap pembelajaran mengidentifikasi jenis makanan hewan dapat ditarik simpulan bahwa penerapan model kooperatif tipe STAD dalam pembelajaran mengidentifikasi jenis makanan siswa di kelas IV SD Negeri Jatiroke I Kecamatan 
Jatinangor Kabupaten Sumedang telah berhasil.

Melalui serangkaian langkah model pembelajaran kooperatif tipe STAD yang meliputi: (1) penyampaian tujuan dan memotivasi siswa; (2) penyajian informasi; (3) pengorganisasian siswa dalam kelompok-kelompok belajar;

pembimbingan kelompok dalam bekerja dan belajar; (5) evaluasi; dan (6) pemberian penghargaan, tampak peningkatan dari data awal sampai akhir siklus 2. Data awal yang diperoleh dari 18 siswa hanya $33 \%$ siswa yang mendapatkan nilai di atas 70, untuk itu peneliti melaksanakan penelitian tindakan kelas dengan menerapkan pembelajaran kooperatif tipe STAD. Pada siklus 1 telah terjadi peningkatan yang signifikan dalam pembelajaran mengidentifikasi jenis makanan hewan. Siswa yang mendapatkan nilai di atas 70 bertambah menjadi 55\%. Di siklus 2 ini dilaksanakan perbaikan yang diperoleh dari siklus 1 dan hasilnya semua siswa atau $100 \%$ siswa mendapatkan nilai di atas 70 .

\section{REFERENSI}

Depdiknas. (2006). Kurikulum Tingkat Satuan Pendidikan. Jakarta: Depdiknas.

Iskandar, S. M. (1997). Pendidikan Ilmu Pengetahuan Alam. Jakarta: DIKTI.

Juwita. (2004). Tipe-tipe pembelajaran kooperatif. Surabaya: UNS.

Muslimin, dkk. (2000). Pembelajaran kooperatif. Surabaya: UNESA.
Saputra, M. Y. (2004). Pembelajaran kooperatif untuk meningkatkan keterampilan anak TK. Bandung: Depdiknas.

Suherman, E. dkk. (2001). Strategi pembelajaran matematika kontemporer. Bandung: FMIPA UPI.

Suherman, E. dkk. (2003). Strategi pembelajaran matematika kontemporer. Bandung: JICA.

Trianto. (2007). pembelajaran inovatif berorientasi konstruktivistik. Jakarta: Prestasi Pustaka Publisher.

Wijayanti, P. (2002). Model pembelajaran kooperatif. [Online]. Tersedia: http://www.pendidikanekonomi.com/2 012/10/modelpembelajarankooperatiftipe.html\#sthas h.Lk7Asx2p.dpuf.

Wiriaatmadja, R. (2005). Metode penelitian tindakan kelas. Bandung: PPs UPI bekerjasama dengan PT. Remaja Rosdakarya. 